\title{
POSSIBLE DISCRIMINATION IN THE WORKPLACE FOLLOWING ACCEPTANCE OR REJECTION OF COVID-19 VACCINATION - OPINIONS OF HUNGARIAN EMPLOYEES
}

\author{
József Poór \\ J. Selye University, Komárno, Slovakia \\ Szonja Jenei \\ Morter Co., Győr, Hungary \\ Szilvia Módosné Szalai \\ J. Selye University, Komárno, Slovakia
}

\begin{abstract}
Hungary is proud of Katalin Karikó, who was born in Hungary and educated at the University of Szeged, including a doctorate level. Later she moved to the United States where gained many practical experiences at several renowned universities as a professor. She has played a key role in the development of the COVID-19 vaccine. This national pride does not mean that every citizen of the country will accept the vaccine unconditionally, however. Their opinions are influenced by their political views, religious backgrounds, life experiences, and the country's turbulent historical past; citizens fear various discriminatory measures. In the first part of our research, the importance of vaccinations and the Hungarian and European regulations are described, followed by the definition of discrimination. In the second section, we demonstrate that sometimes discrimination can be legal. The third part discusses the quantitative research that was conducted about the expected discrimination that can be considered legitimate or illegal. Our opinions are related to foreign travel and the activity of human resource management.
\end{abstract}

Keywords: pandemic, human resource management, vaccine, legal and illegal discrimination

DOI: http://dx.doi.org/10.15549/jeecar.v8i3.668

\section{PROBLEM DEFINITION}

At the end of 2020 and the beginning of 2021, the majority of researchers and scientists dealing with the economic effects of the pandemic did not anticipate that vaccinations, as the way out of it, would divide the population. The issue of discrimination with respect to dealing with the pandemic will soon come to the fore.
Discrimination is not always negative, however, as the interests of the community are often more important than individual freedoms. Because the perception of what is and what is not discrimination is based on opinion, our study only asked for opinions, however those opinions will be the base on which the measures implemented to address the pandemic can be 
examined in the future.

Hungary is proud of Katalin Kariko, a native daughter who lived and taught in the United States of America, and played a key role in the development of the COVID - 19 vaccine. The vaccine, which is linked to her name, was developed using promising and extremely fast technology. It does not contain the full genome of the virus, so it does not cause infection, and it is safe. According to the researcher, the lesson of the pandemic is that decision-makers, businessmen, and politicians all over the world may realize that much more money needs to be spent on education, science, and health care so that the teachers who teach future generation researchers who are obsessed with finding solutions to eternal problems and the doctors and nurses who save people by putting their lives at risk - deserve our respect and financial esteem (Újszászi, 2020).

Because we believe that individual vaccination decisions will be important for experienced researchers and beginners as well, our paper is focused on equity. According to the European regulations, those who accept and reject vaccinations must have equal rights (Zsíros, 2021).

\section{Analysis of recent research and publications}

Vaccines are essential for the prevention of many serious diseases, therefore not only does their role in employment need to be highlighted, but also their role in preserving human life. Over time, vaccinations have made it possible to overcome many heretofore fatal diseases (Tognetti, 2013). The importance of using vaccines lies in the development of immunity. In most cases, a live attenuated vaccine is administered to the body, which constitutes a much lower risk to human health than naturally occurring infection. It can cause at most mild symptoms (Ferenci, 2016).

The development of protection against infection has a long history. Thuküdidész (1985), in his book The Peloponnesian War talked about survivors of the plague, who presumably became immune to the disease, so even if they got the infection again, it was milder the second time and did not endanger their lives (Lőrinc, 2016). The greatest pity was shown by the survivors who recovered and tended to the dying and the sick, however, because they knew well what this disease meant but could feel safe because even if they contracted the disease again it would not be severe or life-threatening. Their fate was considered enviable by the others and by themselves as well. Thuküdidész (1985), noted that they lived in overflowing joy, nurturing the vain hope that no other illnesses might be able to kill them in the future. A further advantage of the vaccination is that herd immunity prevents people from the disease who cannot receive the vaccine (European Commission, 2014). The common goal of the Member States of the European Union is to prevent the spread of communicable diseases and to define the scope of compulsory and recommended vaccinations (European Commission, 2018a).

Citizens who do not trust the government and health care providers are usually informed about vaccinations from unreliable sources. In general, they question the effectiveness of vaccines and oppose immunization campaigns (Lee, Whetten, Omer \& Pan, 2016). The increasing number of Internet users and the spread of online misinformation about vaccines, which has become a global phenomenon, is recognized as a major threat. This problem is particularly widespread in countries in which communication is less efficient and reliable information flow is not ensured (Al-Zaman, 2020). The World Health Organization has announced that the rejection of vaccines and hesitation in getting them are the main threats to global health. Those who do not get vaccinated constitute a serious risk to vulnerable groups of the population: newborns, the elderly, cancer patients, and people whose immune systems are weakened or not functioning properly (European Commission, 2019).

Different rules are applied to vaccinations to prevent various diseases in each member state of the European Union. Childhood vaccination schedules include the following antibodies in all EU and EEA Member States: measles, mumps, rubella, diphtheria, tetanus, whooping cough, polio, Haemophilus influenza type B, and Human papillomavirus. Vaccination schedules for COVID-19, which should be repeated twice, have been established for different specific groups in several member states, but no single draft has been developed (ECDC, 2021).

Germany, the most influential member 
country of the European Union, has a liberal approach to vaccines. Compulsory vaccination is not required by the government, however parents who enroll their children in kindergarten must attend vaccination counseling, and those who refuse to do so may be fined (Eduline / MT, 2019).

With respect to foreign travel and COVID vaccinations a vaccination center for those traveling to Asian, African, tropical, or Mediterranean countries should be visited six weeks before traveling. It is advisable to monitor the timing of this visit, as some vaccines need to be repeated. The vaccination centers also provide full information about the country's being visited COVID protocols (National Vaccination Center, 2020).

Vaccine distrust is a global problem that slows down immunization strategic plans and processes. In 2015, a survey was conducted in 67 participating countries to examine trust in vaccines, their importance, safety, effectiveness, and religious considerations based on public opinion. The survey was part of a project called The State of Vaccine Confidence. The survey revealed that the western and the northern countries are less concerned about vaccine safety than the eastern and the southern countries. This spatial disparity is not limited to Europe, however; the level of concern is higher in the US, Canada and Mexico than in the South American countries (Larson et al., 2016).

Research on the opinion about vaccines examined 20 European countries and found that overall at least $85 \%$ of the respondents in all examined countries believe that vaccines are important. The ratio is about the same for judging the effectiveness of the vaccine and its compatibility with religious views. Another study of the research group revealed that no single strategy could be effective in mitigating mistrust. The following methods have proven to be the most efficient (European Commission, 2018b).

- Targeting unvaccinated and undervaccinated populations.

- Expanding vaccination knowledge and raising the level of awareness.

- Ensuring access to vaccines.

- Targeting specific groups.
- Making vaccination compulsory, applying sanctions.

- Commitment of religious or other influential leaders to promote vaccines.

The COVID-19 virus first appeared in December 2019 in Wuhan Province, China (Chen $\& \mathrm{Yu}, 2019$ ). The epidemic reared its ugly head in a short time all over the world. Initial efforts to stop its spread were in vain; it could only be slowed down with restrictive measures. The only effective solution was the development of a vaccine against it. This process took a long time, however. Various drug treatments, antiviral and immunomodulatory agents had been tried temporarily, with the latter modifying the body's abnormal immune responses (Delang \& Neyts, 2018). The urgent global health crisis necessitated the development of a vaccine as soon as possible. According to a publication written in the summer of 2020 , the first phase of this process had already been completed in the United States, in the United Kingdom, and China, with no or minimal side effects. In areas repeatedly affected by the epidemic, the development of an effective vaccination can be accelerated by carefully planned experiments and cooperation at an international level (Sanicas, Sanicas, Diop \& Montomoli, 2020).

In addition to the three major vaccine manufacturers, smaller pharmaceutical companies had already produced effective products, and, in March 2021, several other vaccines were being developed (Gallagher, 2021). The spread of the pandemic has not only jeopardized the stability of the health care system but has also led to economic problems. Carlos Torres Vila, a well-known Spanish banker, businessman, and CEO of the BBVA Group, drew attention to the fact that the key to recovering from the crisis is to preserve jobs (Canfranc, 2020). For several months, online video conferences have been the venue for personal business meetings. The situation of the automotive industry is not only exacerbated by the pandemic, but the sector also faces several challenges due to stricter environmental regulations, digitalization, and the development of self-propelled vehicles (Roland Berger, 2020). Public opinion fears that the rejection of the vaccine against COVID-19 could be accompanied by discriminatory measures in the workplace. 
The primary goal of companies is to maximize profit, but it cannot be done unlimitedly. Businesses must take into account the responsibility for employment and discrimination should be avoided during their operations (Poór, 2013). In the future, life expectancy and the number of years spent at work are expected to increase due to drug treatments and state-of-the-art technology (Zabelina et al., 2020). The question arises, then, as to whether the trend in the employment of the elderly will be modified by the discriminatory measures due to COVID-19.

Discrimination is prohibited by the rules of the European Union in the area of employment and education on the grounds of race, ethnicity, religion, belief, disability, age, or sexual orientation (European Commission, 2005). Discrimination needs to be protected against, and the necessary forms of redress need to be developed (Karoliny, Poór, 2017). In order to eliminate discrimination, both laws and managers are given a significant role. The elimination of discrimination is positively influenced by the employee-oriented leadership style. The leader feels a responsibility not only for the external stakeholders but also for subordinates. The most important leadership values are manifested in the manager's behavior (Karácsony, 2020).

According to a study conducted in 2019, educated men living in a city suffer the least from discrimination or grievance. People who are marginalized due to their age, health status, or marital status (older and female workers), however, are much more likely to face discrimination in the workplace. Different treatment on the grounds of ethnicity was often reported by the Roma in Hungary (Equal Treatment Authority, 2019).

Internal CSR activity is primarily implemented during the protection of the health of the employees and the education and development of subordinates (Karácsony, 2020). The attitude of the employers towards vaccination and equal treatment in employment can be new elements of corporate social responsibility.

Aim, methods, and hypotheses of our research

Our study aims to determine the opinions of employees in Hungary. We performed computer-assisted data collection in which we also relied on the social capital of the respondents invited to participate in the research. During the transmission of the questionnaire, the contributors, living in different regions of the country, reached male and female respondents of all ages with different qualifications. This approach was necessary because of the continuously changing circumstances; data collection had to be implemented as quickly as possible. Our data are shown to be normally distributed by the Kolmogorov-Smirnov and Shapiro-Wilk tests.

Two types of validation were performed. Appearance validation means that there is a great deal of interest on the part of the respondents. This was verified by completing 30 pilot questionnaires and asking for opinions personally. Content validity was developed with the help of the respondents of the pilot questionnaire. Based on the opinions, we made the following amendments.

- At the beginning of the questionnaire, it is worth emphasizing that it involves two parallel series of questions. Participants of the test found it logical to ask the questions related to probability and acceptability not in pairs, but in isolation from each other.

- The questions related to foreign travel originally included fewer countries. Additional states were added to the questionnaire at the request of the respondents. The added countries were not necessarily the most significant powers of the world, but are popular destinations and countries known and liked by Hungarians.

- We also expanded the list of the examined industries. Justice and agriculture were introduced, again at the suggestion of the respondents.

- The division of the human functions was made according to the literature. No suggestions have been added to this line. Two issues were included in this block, however. One is the effects of age and vaccination, and the other is the impacts of health status and vaccination on generating discrimination.

- As a result of the addition, some $2 \times 44$ questions concerning discrimination were included in the questionnaire as 
independent variables. The questionnaire was complemented by three questions related to attitudes and four other questions related to demographic variables.
Various statistical tests were performed on reliability. The Spearman-Braun test was completed twice on forty items (Tables $1 \mathrm{a}$ and $1 \mathrm{~b})$. The values are high enough (0.997 and 0.991).

Table 1A: Reliability Test 1

\begin{tabular}{|l|l|l|c|}
\hline \multicolumn{3}{|c|}{ Reliability Statistics (1) } \\
\hline \multirow{3}{*}{ Cronbach's Alpha } & \multirow{2}{*}{ Part 1 } & Value & 0.986 \\
\cline { 2 - 4 } & & N of Items & 20 \\
\cline { 2 - 4 } & \multirow{2}{*}{ Part 2 } & Value & 0.989 \\
\cline { 2 - 4 } & & N of Items & 20 \\
\cline { 2 - 4 } & Total N of Items & 40 \\
\hline Correlation Between Forms & & 0.993 \\
\hline Spearman-Brown Coefficient & Equal Length & 0.997 \\
\hline & Unequal Length & 0.997 \\
\hline Guttman Split-Half Coefficient & & 0.994 \\
\hline
\end{tabular}

Source: authors' calculations based on SPSS output.

Table 1B: Reliability test 2

\begin{tabular}{|l|l|l|c|}
\hline \multicolumn{3}{|c|}{ Reliability Statistics (2) } \\
\hline \multirow{3}{*}{ Cronbach's Alpha } & \multirow{2}{*}{ Part 1 } & Value & 0.990 \\
\cline { 2 - 4 } & \multirow{2}{*}{ Part 2 } & N of Items & 20 \\
\cline { 2 - 4 } & & Value & 0.989 \\
\cline { 2 - 4 } & Total N of Items & 20 \\
\hline Correlation Between Forms & \multicolumn{2}{|c|}{} & 40 \\
\hline Spearman-Brown Coefficient & Equal Length & 0.983 \\
\hline & Unequal Length & 0.991 \\
\hline Guttman Split-Half Coefficient & \multicolumn{2}{|c|}{} & 0.991 \\
\hline
\end{tabular}

Source: authors' calculations based on SPSS output.

Reliability was also checked in another way, by calculating Cronbach's Alpha for a large series of related issues. We received sufficiently high values and could not increase the value of Cronbach's Alpha by omitting a question.

The scales were not checked by statistical methods. The 10 grades of the Likert scale were developed because we received many impulsive and extreme opinions, and the scale consists of five elements that could not reflect these attitudes. Responses were obtained over the entire interval of the scale. In addition, dichotomous variables were used. Ordinal scales were included in the questionnaire only in a few cases.

The sample of 209 elements, collected in a manner based on the group sampling principle, represents the active citizens in the domestic 
labor market, meaning, therefore we can use the procedure of inferential statistics. The applied group sampling principle can be regarded as random sampling (Sándorné Kriszt et al., 1997).

Data collection occurred in January 2021, and the evaluation was performed using SPSS software. Quantitative research was carried out. In the first block of the questionnaire, we asked about the probabilities. The block can be subdivided. We first dealt with the issue of enforcing and then the supposed entry restrictions. We asked about the expected individual regulations related to economic activities and the alleged discriminatory measures of human resource management. The next block follows the same structure, but in this case, we looked for answers to prove how legitimate the respondents consider the discussed measures. The third block deals with demographic issues and individual intent. These questions are included in the analysis as independent variables. We based our hypotheses on the individual experience. Due to the preliminary discussions related to the topic, skepticism of the Hungarian population could be assumed. We found a correlation that the discrimination expected in the future does not match the discrimination that was considered to be legitimate. In the same conversations, we sought casual links between the expected and the perceived discrimination and the demographic characteristics. Because no connection was found, we hypothesized that the correlations associated with discrimination did not depend on demographic characteristics, but the attitudes relating to the pandemic and the coronavirus vaccine.

The following hypotheses were formulated:

$\mathrm{H} 1$ : There is a significant difference between the elements of discrimination that are alleged and that are considered legitimate by Hungarian employees.

H2: Data on gender, age, educational attainment and the number of workers in the workplace have little influence on discriminatory measures that are assumed and considered justified by Hungarian employees.

H3: Fear of infection, willingness to be vaccinated and trust in vaccines have a significant influence on discriminatory measures that are assumed and considered justified by Hungarian employees.

\section{RESULTS AND PRESENTATION OF KEY RESEARCH FINDINGS}

\section{Empirical analysis}

The presentation of the results begins with an empirical analysis of the independent variables (Table 2 and Table 3 ). In the case of some delicate or very difficult questions, we have allowed 'refusing to answer' so as not to lose respondents. Therefore, the tables reflect the missing values.

Table 2: Descriptive statistics of the independent factors

\begin{tabular}{|l|c|c|c|c|c|}
\hline \multicolumn{7}{|c|}{ Descriptive Statistics } \\
\hline & $\mathbf{N}$ & Minimum & Maximum & Mean & $\begin{array}{c}\text { Std. } \\
\text { Deviation }\end{array}$ \\
\hline $\begin{array}{l}\text { How much do you fear the } \\
\text { coronavirus infection? }\end{array}$ & 209 & 1 & 10 & 4.30 & 2.852 \\
\hline Do you want to be vaccinated? & 209 & 1 & 3 & 2.15 & 0.806 \\
\hline $\begin{array}{l}\text { To what extent do you feel safe } \\
\text { using the vaccine? }\end{array}$ & 168 & 1 & 10 & 5.08 & 2.953 \\
\hline Gender of respondent. & 209 & 1 & 2 & 1.58 & 0.494 \\
\hline Age of respondent. & 209 & 19 & 63 & 35.90 & 9.552 \\
\hline Highest level of education. & 209 & 1 & 7 & 4.29 & 1.210 \\
\hline $\begin{array}{l}\text { Number of workers at the } \\
\text { company. }\end{array}$ & 176 & 0 & 38000 & 2055.93 & 4902.056 \\
\hline
\end{tabular}

Source: authors' calculations. 
Regarding the evaluation of the first and third independent variables, it should be noted that in the questionnaire the value of 1 indicates total disagreement, and the value of 10 means full agreement, so the average value below 5.5 indicates underrepresented agreement. The second table contains the number of elements, the minimum, maximum, and mean values, as well as the standard deviation. As the number of items exceeds forty, we assume normality. According to Table 2, we can state that the examined population is rather not afraid of coronavirus infection and rather does not consider vaccination safe. However, the willingness to be vaccinated may vary from month to month.

In the case of the second independent variable, the meanings of the codes are as follows: 1 - agreement, want to be vaccinated; 2 - uncertain, may want to be vaccinated; 3 - disagreement, do not want to be vaccinated. The mean value is 2.15 , representing that the examined group of Hungarian workers is rather against vaccination.

Substantial analysis of the responses related to probabilities is included in the next section. Respondents believe that vaccination is more likely to be made mandatory in Hungary and children will be exempted from the obligation (mean 6.36, standard deviation 2.746 and mean 6.00, standard deviation 2.773). Figure 1 shows which countries are assumed to make vaccination mandatory for entry. The dichotomous variable can take the values one or two. Anyone who has selected one believes that it will not be mandatory to administer the vaccine to enter the country.

Figure 1: Probability of the entry barriers

\section{How likely is it that vaccination will be mandatory for foreigners to enter the country?}

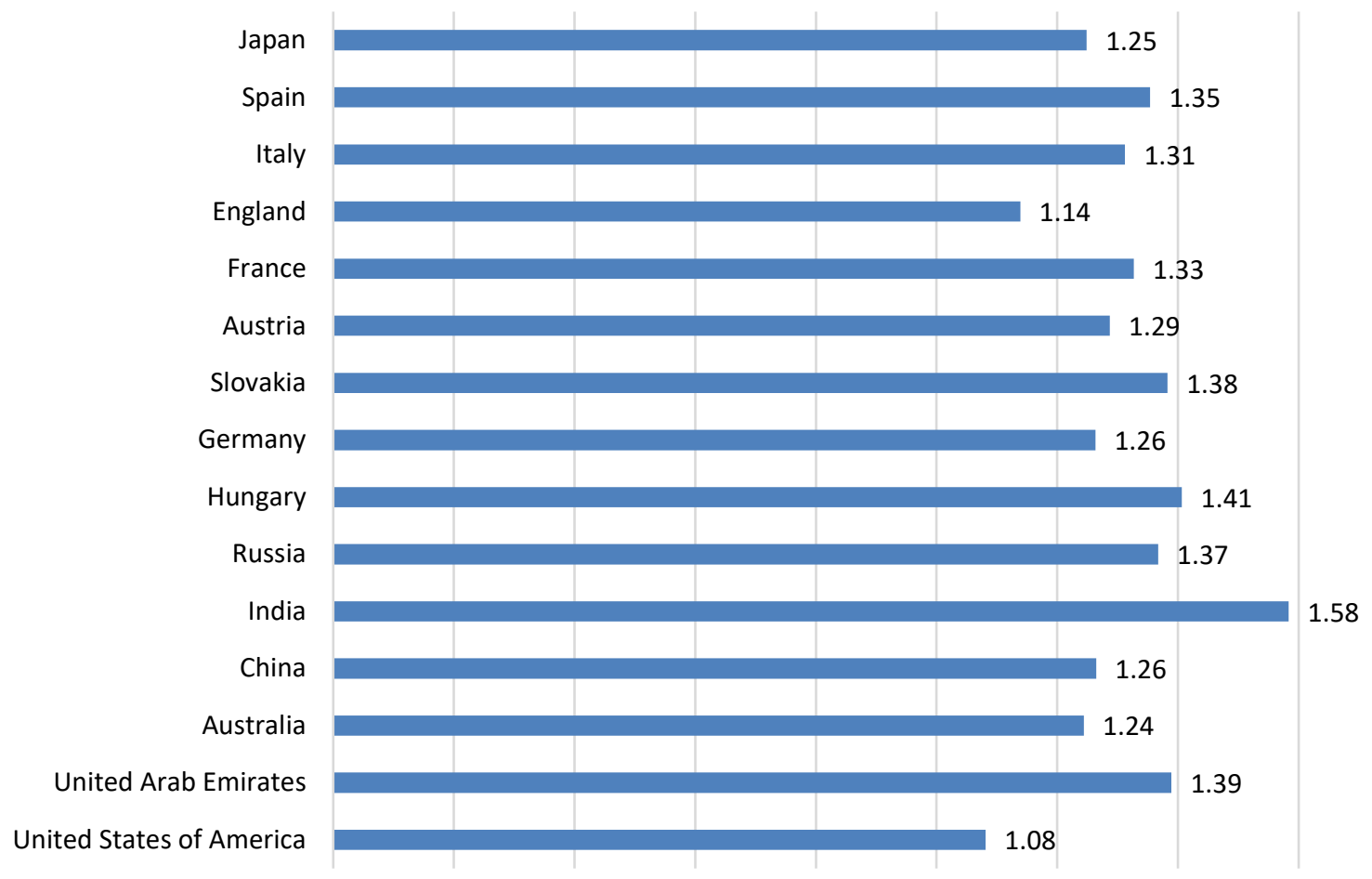

Source: authors' calculations.

Low values indicate that the revival of tourism is a very important aspect that can override safety requirements. We found the highest average in India. In a large and densely populated 
country, the introduction and spread of the virus can have tragic consequences, therefore separation is reasonable. The lowest value is for the USA since the overseas superpower attaches importance to the protection of human rights and respect for the freedom of the individual.

In the case of industry-related questions, we found that people consider it more likely that vaccination will be made mandatory in various industries (Figure 2). The critical sectors are health care (9.22), education (8.36), and tourism (8.17). Our respondents believe that vaccination will not be made mandatory in agriculture (4.88) and the construction industry (4.98). Respondents were also skeptical about the decisions of human resource management. It is believed that discriminatory decisions will be made depending on the vaccination (6.7). Examining each HR function separately, discrimination is most likely to be applied in performance evaluation (1.89) and remuneration (1.87), and least likely in selection (1.37).
Respondents do not regard it acceptable to make vaccination mandatory (4.04). Exemption from vaccination for young people is considered natural (7.03), with an acceptable age being 13 years (13.12). Compared to other countries, Hungarian respondents believe that to protect the country it is more acceptable to make the entry conditional (1.56). The value is also relatively high in the case of Slovakia (1.54). Recently, we have experienced that the closure of the country results in a low number of infections, while the relaxation of discipline associated with restrictions results in unmanageable health situations. Individuals in the sample believe that vaccine-dependent entry is less acceptable in the USA. A lot of people would like to travel freely to this successful country, either as tourists or for work, or, possibly, in connection with their scientific work.

Figure 2: Acceptability of the employers' expectations

How acceptable is it that employers expect to use the vaccine?

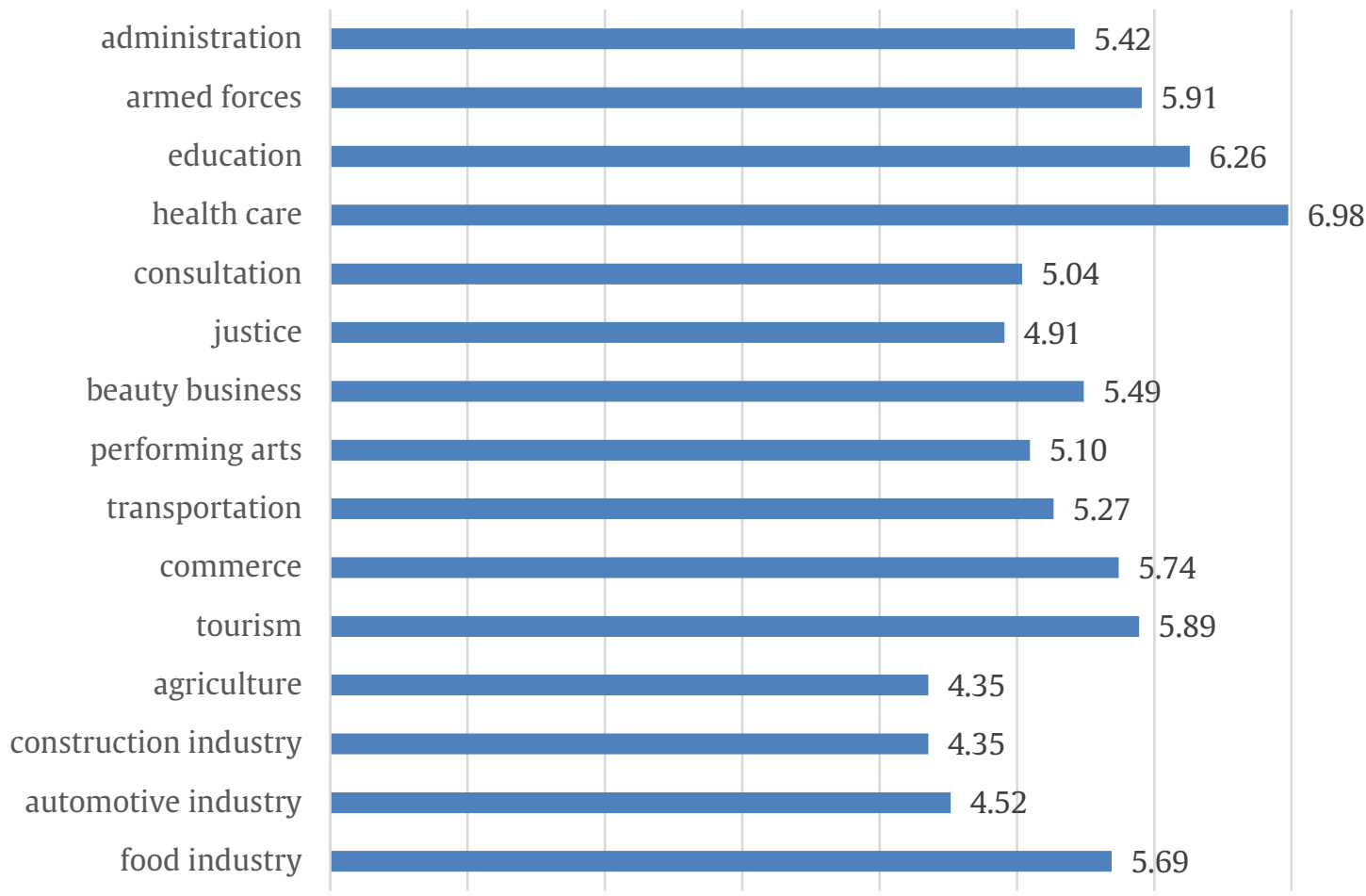

Source: authors' calculations. 
According to the respondents, compulsory vaccination is most acceptable in health care (6.98), in education (6.26), in armed forces (5.91), and in tourism (5.89). In these sectors, it is justified due to the higher risk of infection (Figure 2). These requirements are not regarded as acceptable in agriculture (4.35) and the construction industry (4.35) due to the open-air working in them. Respondents consider vaccinedependent discrimination the most acceptable in remuneration (1.94) and performance evaluation (1.94) (Figure 3). However, discriminatory measures in selection (1.62) are the least acceptable.

Figure 3: Acceptability of the discriminatory measures of Human Resource Management

\section{Is it acceptable that HR will take discriminatory measures during the following functions?}

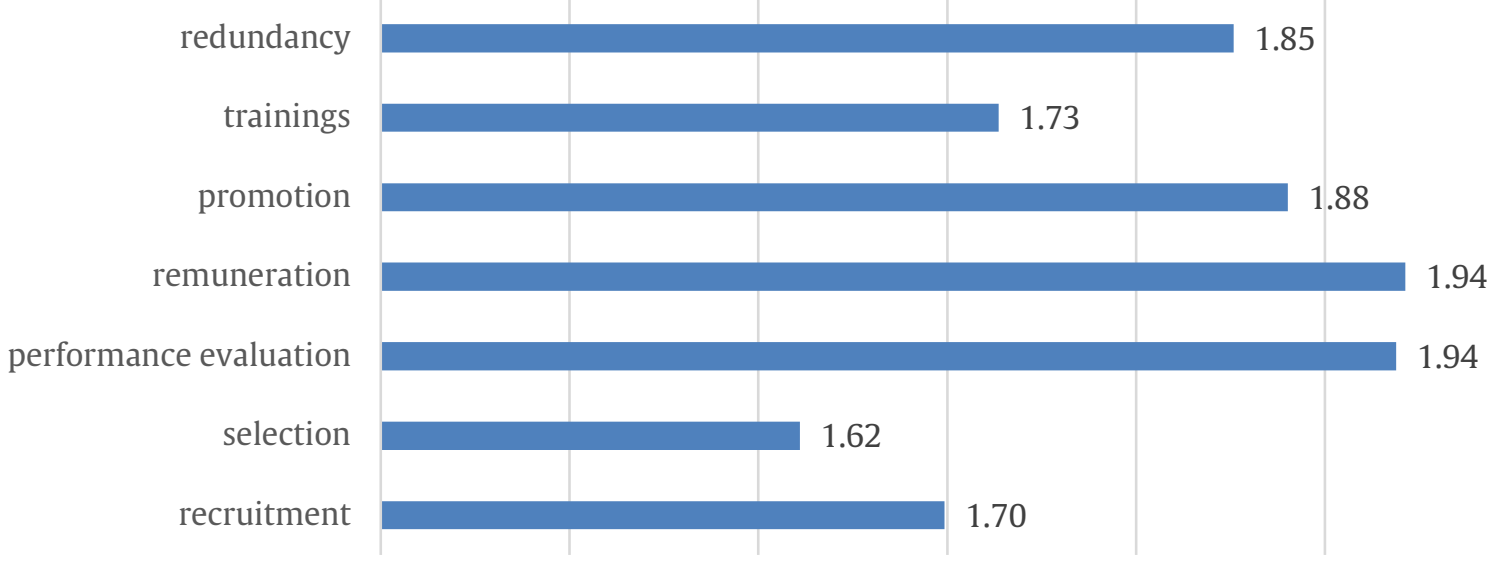

Source: authors' calculations.

\section{Proof of the hypotheses}

According to our first hypothesis, there is a significant difference among Hungarian employees between the discrimination elements that are assumed and considered acceptable. The paired t-test was used for verification. This test compares individual values provided by respondents. The difference means that individuals assume and consider something else acceptable.
Entry based on compulsory vaccination is regarded highly significantly more acceptable, so it is less likely in almost all examined countries (Table 3). The only significant difference was found in favor of acceptance in the case of Hungary and the United Arab Emirates. In the case of India, the values indicate the superiority of probability, but no significance can be discovered. 
Table 3: Probability and acceptability of the entry barriers

\begin{tabular}{|l|c|c|c|c|}
\hline \multicolumn{5}{|c|}{ Paired Samples Test } \\
\hline & $\begin{array}{c}\text { Std. } \\
\text { Deviation }\end{array}$ & $\mathrm{t}$ & $\mathrm{df}$ & Sig. (2-tailed) \\
\hline $\begin{array}{l}\text { United States of } \\
\text { America }\end{array}$ & 0.493 & -7.842 & 173 & 0.000 \\
\hline $\begin{array}{l}\text { United Arab } \\
\text { Emirates }\end{array}$ & 0.570 & -2.395 & 173 & 0.018 \\
\hline Australia & 0.530 & -5.152 & 173 & 0.000 \\
\hline China & 0.553 & -4.116 & 173 & 0.000 \\
\hline India & 0.597 & 1.016 & 173 & 0.311 \\
\hline Russia & 0.611 & -2.975 & 173 & 0.003 \\
\hline Hungary & 0.597 & -2.539 & 173 & 0.012 \\
\hline Germany & 0.558 & -5.706 & 173 & 0.000 \\
\hline Slovakia & 0.563 & -4.040 & 173 & 0.000 \\
\hline Austria & 0.583 & -5.718 & 173 & 0.000 \\
\hline France & 0.563 & -4.447 & 173 & 0.000 \\
\hline England & 0.575 & -7.117 & 173 & 0.000 \\
\hline Italy & 0.562 & -3.236 & 173 & 0.001 \\
\hline Spain & 0.599 & -3.289 & 173 & 0.001 \\
\hline Japan & 0.549 & -4.420 & 173 & 0.000 \\
\hline Source: authors & & & & \\
\hline
\end{tabular}

Source: authors' calculations.

Mistrust towards employers is represented by the fact that the introduction of vaccination obligation is considered highly significantly more likely than acceptable in most industries (Table 4). Agriculture also has a weaker significance. Landowners may have strict expectations, which reflect the traditional landowner-farmer relationship.

Respondents consider highly significantly more likely than acceptable that human resource management will take discriminatory measures depending on vaccination (Table 5). Discriminatory decisions based on vaccination, age, and health status are also considered more likely. Interestingly, in the case of human functions, the acceptance of the measures is significantly higher than the probability of them. Except for recruitment, significant and highly significant differences were found in the case of selection, performance evaluation, remuneration, promotion, participation in training courses, and redundancy. 
Table 4: Probability and acceptability of the employers' expectations in different industries

\begin{tabular}{|l|c|c|c|c|}
\hline \multicolumn{5}{|c|}{ Paired Samples Test } \\
\hline & $\begin{array}{c}\text { Std. } \\
\text { Deviation }\end{array}$ & $\mathbf{t}$ & df & Sig. (2-tailed) \\
\hline food industry & 3.533 & 6.676 & 208 & 0.000 \\
\hline automotive industry & 3.342 & 4.864 & 208 & 0.000 \\
\hline construction industry & 3.119 & 2.906 & 208 & 0.004 \\
\hline agriculture & 3.149 & 2.417 & 208 & 0.017 \\
\hline tourism & 3.350 & 9.849 & 208 & 0.000 \\
\hline commerce & 3.340 & 8.492 & 208 & 0.000 \\
\hline transportation & 3.325 & 8.072 & 208 & 0.000 \\
\hline performing arts & 3.268 & 5.249 & 208 & 0.000 \\
\hline beauty business & 3.298 & 6.502 & 208 & 0.000 \\
\hline justice & 3.039 & 6.054 & 208 & 0.000 \\
\hline consultation & 3.192 & 5.005 & 208 & 0.000 \\
\hline health care & 3.404 & 9.530 & 208 & 0.000 \\
\hline education & 3.364 & 9.048 & 208 & 0.000 \\
\hline armed forces & 3.421 & 9.341 & 208 & 0.000 \\
\hline administration & 3.326 & 9.069 & 208 & 0.000 \\
\hline
\end{tabular}

Source: authors' calculations.

As indicated above, we can state that our first hypothesis was fulfilled. Respondents have different visions from the acceptable and legitimate measures of the countries, industries, and human resource management. According to our second hypothesis, gender, age, education, and the number of employees in the workplace have little influence on the discriminatory measures that are assumed and regarded as acceptable by Hungarian employees. The significance of correlations of the causal links between the dependent and independent variables can be found in Tables $6 \mathrm{~A}$ and $6 \mathrm{~B}$.

Significant and highly significant cases are marked in green. Demographic variables are less likely to show significant relationships. The explanation of it will be part of our publication. The vertical axis contains the number of questions representing the dependent variable, and the horizontal axis contains the expression referring to the influencing factor. This allows us to answer our second and third hypotheses. According to the second hypothesis, demographic characteristics have a minimal impact on responses. Gender, education, and age equally affected seven responses significantly. The impact of the number of employees in the workplace can be demonstrated in eight cases. 
Table 5: Probability and acceptability of the discriminatory measures of Human Resource Management

\begin{tabular}{|l|c|c|c|c|}
\hline \multicolumn{5}{|c|}{ Paired Samples Test } \\
\hline & $\begin{array}{c}\text { Std. } \\
\text { Deviation }\end{array}$ & $\mathbf{t}$ & $\mathrm{df}$ & Sig. (2-tailed) \\
\hline $\begin{array}{l}\text { discriminatory measures } \\
\text { depending on vaccination }\end{array}$ & 3.678 & 12.430 & 208 & 0.000 \\
\hline $\begin{array}{l}\text { discriminatory measures } \\
\text { depending on age and } \\
\text { vaccination }\end{array}$ & 3.709 & 12.065 & 208 & 0.000 \\
\hline $\begin{array}{l}\text { discriminatory measures } \\
\text { depending on health status } \\
\text { and vaccination }\end{array}$ & 3.698 & 12.120 & 208 & 0.000 \\
\hline $\begin{array}{l}\text { discriminatory measures } \\
\text { during recruitment }\end{array}$ & 0.502 & -1.516 & 208 & 0.131 \\
\hline $\begin{array}{l}\text { discriminatory measures } \\
\text { during selection }\end{array}$ & 0.544 & -6.739 & 208 & 0.000 \\
\hline $\begin{array}{l}\text { discriminatory measures } \\
\text { during performance } \\
\text { evaluation }\end{array}$ & 0.356 & -2.135 & 208 & 0.034 \\
\hline $\begin{array}{l}\text { discriminatory measures } \\
\text { during remuneration }\end{array}$ & 0.359 & -3.085 & 208 & 0.002 \\
\hline $\begin{array}{l}\text { discriminatory measures } \\
\text { during promotion }\end{array}$ & 0.466 & -5.197 & 208 & 0.000 \\
\hline $\begin{array}{l}\text { discriminatory measures } \\
\text { during trainings }\end{array}$ & 0.512 & -4.596 & 208 & 0.000 \\
\hline $\begin{array}{l}\text { discriminatory measures } \\
\text { during redundancy }\end{array}$ & 0.490 & -7.051 & 208 & 0.000 \\
\hline
\end{tabular}

Source: authors' calculations.

These numbers are interesting when we compare them to the values of hypothesis 3 . The fear of coronavirus significantly affected responses in 54 cases, willingness to receive the vaccine in 58 cases, and considering the vaccine safe in 47 cases. Given the above, our hypotheses can be regarded as justified, however, the analyses of some other correlations still complement our paper. 
Table 6A: Significance of correlations between the independent factors and probability

\begin{tabular}{|c|c|c|c|c|c|c|c|}
\hline \multirow{3}{*}{$\begin{array}{l}\text { Dependent } \\
\text { factors }\end{array}$} & \multicolumn{7}{|c|}{ Independent factors } \\
\hline & Fear & Want & Safe & Gender & Age & Education & Number \\
\hline & $\begin{array}{l}\text { Sig. (2- } \\
\text { tailed) }\end{array}$ & $\begin{array}{l}\text { Sig. (2- } \\
\text { tailed) }\end{array}$ & $\begin{array}{l}\text { Sig. (2- } \\
\text { tailed) }\end{array}$ & $\begin{array}{l}\text { Sig. (2- } \\
\text { tailed) }\end{array}$ & $\begin{array}{l}\text { Sig. (2- } \\
\text { tailed) }\end{array}$ & $\begin{array}{l}\text { Sig. (2- } \\
\text { tailed) }\end{array}$ & $\begin{array}{l}\text { Sig. (2- } \\
\text { tailed) }\end{array}$ \\
\hline 1 & 0.367 & 0.423 & 0.777 & 0.025 & 0.934 & 0.170 & 0.678 \\
\hline 2 & 0.126 & 0.930 & 0.495 & 0.565 & 0.002 & 0.874 & 0.170 \\
\hline 3 & 0.446 & 0.364 & 0.726 & 0.234 & 0.907 & 0.750 & 0.336 \\
\hline 4 & 0.032 & 0.090 & 0.367 & 0.326 & 0.006 & 0.659 & 0.490 \\
\hline 5 & 0.103 & 0.035 & 0.058 & 0.471 & 0.678 & 0.930 & 0.349 \\
\hline 6 & 0.076 & 0.008 & 0.003 & 0.690 & 0.616 & 0.726 & 0.824 \\
\hline 7 & 0.445 & 0.106 & 0.622 & 0.473 & 0.062 & 0.884 & 0.389 \\
\hline 8 & 0.243 & 0.203 & 0.510 & 0.430 & 0.835 & 0.490 & 0.758 \\
\hline 9 & 0.095 & 0.086 & 0.891 & 0.480 & 0.431 & 0.032 & 0.323 \\
\hline 10 & 0.131 & 0.488 & 0.216 & 0.861 & 0.708 & 0.781 & 0.072 \\
\hline 11 & 0.007 & 0.014 & 0.018 & 0.105 & 0.268 & 0.624 & 0.773 \\
\hline 12 & 0.109 & 0.057 & 0.119 & 0.931 & 0.105 & 0.414 & 0.248 \\
\hline 13 & 0.076 & 0.040 & 0.076 & 0.214 & 0.738 & 0.095 & 0.557 \\
\hline 14 & 0.016 & 0.015 & 0.016 & 0.246 & 0.496 & 0.390 & 0.947 \\
\hline 15 & 0.452 & 0.378 & 0.215 & 0.016 & 0.588 & 0.380 & 0.764 \\
\hline 16 & 0.001 & 0.016 & 0.040 & 0.585 & 0.034 & 0.328 & 0.669 \\
\hline 17 & 0.012 & 0.008 & 0.104 & 0.351 & 0.018 & 0.045 & 0.973 \\
\hline 18 & 0.007 & 0.001 & 0.083 & 0.279 & 0.154 & 0.888 & 0.511 \\
\hline 19 & 0.037 & 0.005 & 0.335 & 0.830 & 0.835 & 0.554 & 0.087 \\
\hline 20 & 0.043 & 0.000 & 0.059 & 0.689 & 0.455 & 0.431 & 0.040 \\
\hline 21 & 0.022 & 0.000 & 0.037 & 0.820 & 0.951 & 0.866 & 0.036 \\
\hline 22 & 0.010 & 0.001 & 0.102 & 0.773 & 0.354 & 0.677 & 0.044 \\
\hline 23 & 0.070 & 0.068 & 0.685 & 0.205 & 0.957 & 0.474 & 0.207 \\
\hline 24 & 0.021 & 0.001 & 0.351 & 0.547 & 0.795 & 0.527 & 0.418 \\
\hline 25 & 0.036 & 0.091 & 0.694 & 0.146 & 0.799 & 0.025 & 0.064 \\
\hline 26 & 0.018 & 0.000 & 0.042 & 0.977 & 0.511 & 0.154 & 0.554 \\
\hline 27 & 0.004 & 0.005 & 0.535 & 0.662 & 0.339 & 0.205 & 0.189 \\
\hline 28 & 0.006 & 0.000 & 0.029 & 0.243 & 0.604 & 0.112 & 0.029 \\
\hline 29 & 0.022 & 0.004 & 0.228 & 0.778 & 0.556 & 0.562 & 0.056 \\
\hline 30 & 0.111 & 0.104 & 0.674 & 0.007 & 0.702 & 0.283 & 0.312 \\
\hline 31 & 0.007 & 0.162 & 0.635 & 0.059 & 0.513 & 0.558 & 0.221 \\
\hline 32 & 0.004 & 0.006 & 0.026 & 0.015 & 0.956 & 0.405 & 0.023 \\
\hline 33 & 0.002 & 0.026 & 0.408 & 0.854 & 0.252 & 0.331 & 0.040 \\
\hline 34 & 0.397 & 0.840 & 0.324 & 0.492 & 0.664 & 0.004 & 0.449 \\
\hline 35 & 0.643 & 0.741 & 0.227 & 0.756 & 0.995 & 0.373 & 0.888 \\
\hline
\end{tabular}


Table 6A: Continued

\begin{tabular}{|l|l|l|l|l|l|l|l|}
\hline 36 & 0.892 & 0.466 & 0.133 & 0.833 & 0.683 & 0.108 & 0.663 \\
\hline 37 & 0.852 & 0.403 & 0.714 & 0.727 & 0.171 & 0.388 & 0.974 \\
\hline 38 & 0.388 & 0.751 & 0.431 & 0.152 & 0.603 & 0.547 & 0.734 \\
\hline 39 & 0.986 & 0.089 & 0.259 & 0.008 & 0.727 & 0.218 & 0.090 \\
\hline 40 & 0.549 & 0.667 & 0.926 & 0.582 & 0.039 & 0.406 & 0.047 \\
\hline 41 & 0.217 & 0.972 & 0.742 & 0.358 & 0.633 & 0.467 & 0.085 \\
\hline 42 & 0.319 & 0.991 & 0.752 & 0.274 & 0.894 & 0.011 & 0.697 \\
\hline 43 & 0.361 & 0.091 & 0.068 & 0.513 & 0.399 & 0.465 & 0.845 \\
\hline 44 & 0.696 & 0.860 & 0.547 & 0.226 & 0.135 & 0.916 & 0.279 \\
\hline
\end{tabular}

Source: authors' calculations.

Table 6B: Significance of correlations between the independent factors and acceptability

\begin{tabular}{|c|c|c|c|c|c|c|c|}
\hline \multirow{3}{*}{$\begin{array}{l}\text { Dependent } \\
\text { factors }\end{array}$} & \multicolumn{7}{|c|}{ Independent factors } \\
\hline & Fear & Want & Safe & Gender & Age & Education & Number \\
\hline & $\begin{array}{l}\text { Sig. (2- } \\
\text { tailed) }\end{array}$ & $\begin{array}{l}\text { Sig. (2- } \\
\text { tailed) }\end{array}$ & $\begin{array}{l}\text { Sig. (2- } \\
\text { tailed) }\end{array}$ & $\begin{array}{l}\text { Sig. (2- } \\
\text { tailed) }\end{array}$ & $\begin{array}{l}\text { Sig. (2- } \\
\text { tailed) }\end{array}$ & $\begin{array}{l}\text { Sig. (2- } \\
\text { tailed) }\end{array}$ & $\begin{array}{l}\text { Sig. (2- } \\
\text { tailed) }\end{array}$ \\
\hline 45 & 0.000 & 0.000 & 0.000 & 0.942 & 0.405 & 0.093 & 0.818 \\
\hline 46 & 0.001 & 0.000 & 0.000 & 0.734 & 0.024 & 0.001 & 0.151 \\
\hline 47 & 0.746 & 0.009 & 0.041 & 0.360 & 0.020 & 0.147 & 0.958 \\
\hline 48 & 0.000 & 0.000 & 0.000 & 0.580 & 0.805 & 0.883 & 0.342 \\
\hline 49 & 0.000 & 0.000 & 0.000 & 0.838 & 0.608 & 0.092 & 0.644 \\
\hline 50 & 0.000 & 0.000 & 0.000 & 0.559 & 0.538 & 0.642 & 0.209 \\
\hline 51 & 0.000 & 0.000 & 0.000 & 0.372 & 0.202 & 0.514 & 0.833 \\
\hline 52 & 0.000 & 0.000 & 0.000 & 0.175 & 0.985 & 0.483 & 0.398 \\
\hline 53 & 0.000 & 0.000 & 0.000 & 0.267 & 0.701 & 0.320 & 0.347 \\
\hline 54 & 0.000 & 0.000 & 0.000 & 0.111 & 0.733 & 0.187 & 0.709 \\
\hline 55 & 0.000 & 0.000 & 0.000 & 0.287 & 0.985 & 0.667 & 0.307 \\
\hline 56 & 0.000 & 0.000 & 0.000 & 0.316 & 0.602 & 0.286 & 0.542 \\
\hline 57 & 0.000 & 0.000 & 0.000 & 0.252 & 0.984 & 0.665 & 0.370 \\
\hline 58 & 0.000 & 0.000 & 0.000 & 0.073 & 0.789 & 0.999 & 0.404 \\
\hline 59 & 0.000 & 0.000 & 0.000 & 0.159 & 0.737 & 0.664 & 0.331 \\
\hline 60 & 0.000 & 0.000 & 0.000 & 0.237 & 0.904 & 0.780 & 0.405 \\
\hline 61 & 0.000 & 0.000 & 0.000 & 0.172 & 0.937 & 0.839 & 0.365 \\
\hline 62 & 0.000 & 0.000 & 0.000 & 0.326 & 0.697 & 0.944 & 0.410 \\
\hline 63 & 0.000 & 0.000 & 0.000 & 0.741 & 0.129 & 0.176 & 0.397 \\
\hline 64 & 0.000 & 0.000 & 0.000 & 0.687 & 0.544 & 0.274 & 0.493 \\
\hline 65 & 0.000 & 0.000 & 0.000 & 0.618 & 0.176 & 0.231 & 0.526 \\
\hline 66 & 0.000 & 0.000 & 0.000 & 0.852 & 0.103 & 0.184 & 0.480 \\
\hline 67 & 0.000 & 0.000 & 0.000 & 0.884 & 0.259 & 0.304 & 0.392 \\
\hline 68 & 0.000 & 0.000 & 0.000 & 0.887 & 0.469 & 0.343 & 0.496 \\
\hline
\end{tabular}


Table 6A: Continued

\begin{tabular}{|l|l|l|l|l|l|l|l|}
\hline 69 & 0.000 & 0.000 & 0.000 & 0.602 & 0.250 & 0.325 & 0.243 \\
\hline 70 & 0.000 & 0.000 & 0.000 & 0.547 & 0.399 & 0.379 & 0.420 \\
\hline 71 & 0.000 & 0.000 & 0.000 & 0.590 & 0.476 & 0.328 & 0.541 \\
\hline 72 & 0.000 & 0.000 & 0.000 & 0.602 & 0.411 & 0.396 & 0.429 \\
\hline 73 & 0.000 & 0.000 & 0.000 & 0.780 & 0.267 & 0.315 & 0.546 \\
\hline 74 & 0.000 & 0.000 & 0.000 & 0.905 & 0.170 & 0.302 & 0.170 \\
\hline 75 & 0.000 & 0.000 & 0.000 & 0.729 & 0.200 & 0.110 & 0.189 \\
\hline 76 & 0.000 & 0.000 & 0.000 & 0.750 & 0.602 & 0.475 & 0.454 \\
\hline 77 & 0.000 & 0.000 & 0.000 & 0.947 & 0.680 & 0.473 & 0.215 \\
\hline 78 & 0.000 & 0.000 & 0.000 & 0.303 & 0.169 & 0.333 & 0.349 \\
\hline 79 & 0.000 & 0.000 & 0.000 & 0.112 & 0.185 & 0.274 & 0.363 \\
\hline 80 & 0.000 & 0.000 & 0.000 & 0.096 & 0.128 & 0.440 & 0.408 \\
\hline 81 & 0.170 & 0.106 & 0.079 & 0.946 & 0.793 & 0.542 & 0.594 \\
\hline 82 & 0.131 & 0.007 & 0.023 & 0.974 & 0.731 & 0.936 & 0.425 \\
\hline 83 & 0.107 & 0.481 & 0.821 & 0.008 & 0.564 & 0.039 & 0.339 \\
\hline 84 & 0.576 & 0.157 & 0.127 & 0.070 & 0.714 & 0.532 & 0.045 \\
\hline 85 & 0.353 & 0.202 & 0.135 & 0.493 & 0.541 & 0.620 & 0.921 \\
\hline 86 & 0.697 & 0.038 & 0.022 & 0.476 & 0.718 & 0.217 & 0.240 \\
\hline 87 & 0.511 & 0.588 & 0.832 & 0.667 & 0.825 & 0.860 & 0.315 \\
\hline 88 & 0.135 & 0.000 & 0.003 & 0.004 & 0.231 & 0.886 & 0.330 \\
\hline
\end{tabular}

Source: authors' calculations.

In the case of women, it can be observed that vaccination is considered more likely to be made mandatory, in general, and both in the sectors of health care and armed forces. Female respondents recognize the frequency of unavoidable contacts in health care and consider it likely that those taking care of the country's defense need to be protected from the virus. It is considered probable and acceptable that the administration of vaccination should be taken into account during performance evaluation. The older the respondent is, the more he assumes and at the same time accepts that children should be excluded from the vaccination program. As people get older, they increasingly have confidence in the vaccination flexibility of the United States, not considering it likely to make vaccination compulsory for entry. Younger respondents regard it as likely that remuneration will also be influenced by the artificial acquisition of immunity.

In the context of qualification, some other correlations are highlighted. The more educated the respondent is, the less he regards it as likely that human resource management will take discriminatory measures due to a lack of vaccination. Individuals with higher education believe that vaccination will have less influence on training. Aptitude, competencies, and willingness to further training will be decisive criteria. It is less acceptable for people with higher education to exempt children from the vaccination obligation, as they are more informed and able to assess the benefits of having the highest number of compulsory childhood vaccinations in Hungary among the European countries (ECDC, 2021).

Employees working for a larger company consider it more likely to make vaccination mandatory in the automotive industry and less likely to influence remuneration. They recognize that personal contact is inevitable in large organizations and wages depend on the position and performance. Respondents who are more afraid of coronavirus infection consider it less likely to make vaccination mandatory in several countries. Anyone who prefers to vaccinate himself regards it more likely to make 
vaccination compulsory in some professions. People who find vaccination safer believe that the entry restrictions are more acceptable for all countries, and the vaccination obligation is more acceptable in the case of all professions. However, regarding human resource measures, discriminatory decisions are better supported in the case of recruitment and training.

\section{Conclusions and recommendations}

We came to several main and some subfindings in the course of our research. The most important is that there is a significant difference between the discrimination that is alleged and considered acceptable. Some of the distinctions are accepted by the public. This is typical in cases when forcing the individual to vaccinate serves the interest of the community. Communities can be countries, professions, or employees of a company. The fact that something else is assumed and considered to be acceptable indicates a different way of thinking from the governments, the sector management, or the corporate management.

Gender, age, education, and the number of employees have only a small effect on the perceptions about discrimination that is assumed and considered acceptable. Age has minimal impact on responses. In this context, it is important to note that we conducted our study only among employees. If retirees had been included in the sample, different results might have been obtained. The related findings are not repeated in this section.

Opinions about discrimination mainly depend on the trinity of fear, will, and trust. Views are shaped by how much the individual is afraid of infection, how much they want to be vaccinated and how much they trust the vaccines available on the market.

The primary benefit of our research is to explore the context that governments have the responsibility to clarify and communicate to citizens the prohibited, tolerated, and potentially supported discrimination elements. Fighting against the consequences of the virus is a major challenge for all governments around the world, but it is also necessary to eliminate uncertainty about the future to gain the full confidence of citizens. In order to influence people's ideas about travel, industrial obligations, and human discrimination, the willingness to administer the vaccination and the feeling of safety associated with the vaccine should be increased.

We hope that talented researchers will choose vaccination, and if for some reason they cannot do so, their careers, international presences, and successes will not be negatively affected by abstaining from vaccination.

In our research, we were curious about the opinion of the public, which was completely topical at the time of the survey. At that time, no one knew what to expect about discrimination. There is already a debate in the public media about possible discrimination. The research cannot be used in the same form. Building on the same basis, we can ask to what extent the respondent agrees with the experienced discrimination. In this case, there would be no comparison of probability and acceptability. The research should not be conducted only in Hungary. After country-specific validation, the countries of travel destination, the examined industries, and the possibly HR activities can be modified.

In the case of this type of paper, it would be expected to present the results of such research studies and a discussion based on it. So far, very few people have researched the topic. We can fully agree with the following statement: Vaccination certificates must be handled responsibly and under scientific management to ensure a fair procedure for all of us (Dye \& Mills, 2021).

We can expect positive and negative discrimination as well. The extent of it depends on the respect for individual freedoms, community health considerations, the interests of corporate human resource management, and the rationality, humanity, and attitudes of decision-makers towards vaccination.

\section{REFERENCES}

Al-Zaman, M. S. (2020). COVID-19-related online misinformation in Bangladesh. Journal of Health Research. DOI: 10.1108/JHR-09-2020-0414.

Bosco, D. (2020). 2008 vs. 2020: A financial crisis comparison. CliftonLarsonAllen LLP.

Retrieved February 10, 2021, from: https://www.claconnect.com/resourc es/articles/2020/2008-vs-2020-a-financial- 
crisis-comparison

Canfranc, M., R. (2020). From the great recession to the great pandemic: the differences between the 2008 and 2020 crises. Banco Bilbao Vizcaya Argentaria, S.A. Retrieved February 5, 2021

from: https://www.bbva.com/en/from-thegreat-recession-to-the-great-pandemic-thedifferences-between-the-2008-and-2020crises/

Chen, X., \& Yu, B. (2020). First two months of the 2019 coronavirus disease (COVID-19) epidemic in China: real-time surveillance and evaluation with a second derivative model. Global health research and policy 5(7). https://doi.org/10.1186/s41256020-00137-4.

Delang, L., \& Neyts, J. (2020). Medical treatment options for COVID-19. European Heart Journal: Acute Cardiovascular Care, 9(3), 209-214. DOI: 10.1177/2048872620922790.

Dye, C., \& Mills, M. C. (2021). COVID-19 vaccination passports. Science, 371(6535), 1184. DOI: $10.1126 /$ science.abi5245.

Eduline/MT (2019). Agreed: measles vaccination will be mandatory for all pre-school and school children in Germany. (In Hungarian). Retrieved January 3, 2021, from:https://eduline.hu/kozoktatas/201911 15_kotelezo_kanyaro_oltas

Equal Treatment Authority and Social Sciences Research Center Institute of Sociology (2019). Personal and social perception of discrimination and legal awareness of the right to equal treatment survey findings 2019. Budapest, Hungary: Equal Treatment Authority Publishing House Co.

European Centre for Disease Prevention and Control (2021). Vaccine schedules in all countries of the European Union. Retrieved January 3, 2021, from:https://vaccineschedule.ecdc.europa.eu/

European Commission (2005). Fight against discrimination in the European Union. Directorate-General for Employment, Social Affairs and Equal Opportunities. (In Hungarian). Brussels, Belgium: European Commission Publishing Office.

European Commission (2014). Information and announcements. C438. Official Journal of the
European Union. (In Hungarian). 57(1), 3-7.

European Commission (2018a). Medical countermeasures - vaccines and immunizations. Vaccination - the most important element of primary prevention in public health. (In Hungarian). Brussels, Belgium: European Commission Publishing Office. DOI: 10.2818/259159.

European Commission (2018b): Vaccination programmes and health systems in the European Union. report of the expert panel on effective ways of investing in health (EXPH). Luxembourg, Luxembourg: Publications Office of the European Union. DOI: $10.2875 / 18503$.

Ferenci, T. (2014). Vaccinations based on facts. (In Hungarian). Budapest, Hungary: Medicina Publishing House Co.

Gallagher, J. (2021). Covid vaccine update: Those that work - and the others on the way. $B B C$ News. Retrieved February 2, 2021, from: https://www.bbc.com/news/health51665497

Jarrett, C., Wilson, R., O'Leary, M., Eckersberger, E. \& Larson, H. J. (2015). Strategies for addressing vaccine hesitancy. The official journal of The Edward Jenner Society and The Japanese Society for Vaccinology. Vaccine 33, 41804190. https://doi.org/10.1In Hu016/j.vaccine .2015.04.040.

Karácsony, P. (2020). Analyzing the relationship between leadership style and corporate social responsibility in Hungarian small and medium-sized enterprises. Acta Polytechnica Hungarica. 17(7), 183-198. DOI:10.12700/aph.17.7.2020.7.10.

Karoliny M., \& Poór J. (2017). Human resource management handbook. (In Hungarian). Budapest: Wolters Kluwer Hungary Kft.

Larson, H. J., de Figueiredo, A., Xiahong, Z., Schulz, W. S., Verger, P., Johnston, I. G., Cook, A. R., \& Jones, N. S. (2016). The state of vaccine confidence 2016: Global insights through a 67-country survey. EBiomedicine 12(C), 295-301. DOI: 10.1016/j.ebiom.2016.08.042.

Lee, C., Whetten, C., Omer, S. B., \& Pan, W. K. Y. (2016). Hurdles to herd immunity: Distrust of government and vaccine refusal in the US, 
2002-2003. Vaccine. 34(34):3972-8. doi: 10.1016/j.vaccine.2016.06.048.

Lőrinc L. (2016). Lifestyle. (In Hungarian). Budapest, Hungary: Academic Publishing House Co. https://doi.org/10.1556/9789630597470.

National Vaccination Center Ltd. (2020). Pretravel and health vaccinations. Retrieved January 10, 2021, from: https://oltokozpont.hu/hu.

Palmer, R. (2019). Vaccine hesitancy: public health emergency. EUROPE \& VACCINES For effective vaccination policies in Europe. The European Files. Retrieved January 10, 2021, from: https://www.europeanfiles.eu/wpcontent/uploads/2019/11/Europe-VaccinesFor-effective-vaccination-policies-inEurope-issue-60.pdf

Poór J. (2013). Internalization and globalization in management. (In Hungarian). Budapest: Wolters Kluwer Kft.

Roland Berger GmbH (2020). This crisis is different - comparing the coronavirus crisis with the financial crash. Latest update of our corona economic impact series. Roland Berger: Retrieved January 15, 2021, from: https://www.rolandberger.com/en/Ins ights/Publications/This-crisis-is-differentComparing-the-coronavirus-crisis-with-thefinancial.html

Sanicas, M., Sanicas, M., Diop, D., \& Montomoli, E. (2020). A review of COVID-19 vaccines in development: 6 months into the pandemic. Pan African Medical Journal, 37(124). doi:

10.11604/pamj.2020.37.124.24973.

Sándorné Kriszt, É., Varga, E., Veitzné Kenyeres, E., Korpás, A., \& Csernyák, L. (1997). General statistics II. (In Hungarian). National Publishing Co.

Thuküdidész (1985). The Peloponnesian war. (In Hungarian). Budapest, Hungary: Europa Publishing Co. Retrieved January 16, 2021, from: https://mek.oszk.hu/16400/16477/16 477.pdf

Tognotti, E. (2013). Lessons from the history of quarantine, from plague to influenza a. emerging infectious diseases. 19(2), 254259. doi: 10.3201/eid1902.120312.
Trouillard, S. (2020). Katalin Kariko, the scientist behind the Pfizer COVID-19 vaccine. France 24. Retrieved January 13, 2021, from: https://www.france24.com/en/americ as/20201218-katalin-kariko-the-scientistbehind-the-pfizer-covid-19-vaccine

Újszászi, I. (2020). Katalin Kariko, an alumnus of SZTE, is one of the founders of the most promising vaccine development against coronavirus. (In Hungarian). Magazine of University Szeged. 2020(1), 14-15.

Zabelina, O., Shubenkova, E., Mirzabaeva, F., Voykina, E., Kucherenko, K., Czibula, A., \& Karacsony, P. (2020). Lifelong education: challenges of the digital economy. Komarno, Slovakia: Janos Selye University.

Zsíros, S. (2021). According to the EU, those who refuse vaccination should not be discriminated. (In Hungarian) Euronews. Retrieved February 5, 2021 from: https://hu.euronews.com/2021/01/19 /az-eu-szerint-nem-szabad-diszkriminalniaz-oltastelutasitokat?fbclid=IwAR1Hfdt7pk9xiATGbbP5cZhszdFquDx42m7h07VEicqr73fJA LIpq1w9F8

\section{CORRESPONDING AUTHOR}

Dr. József Poór, email: $\quad$ poorjf@t-online.hu 